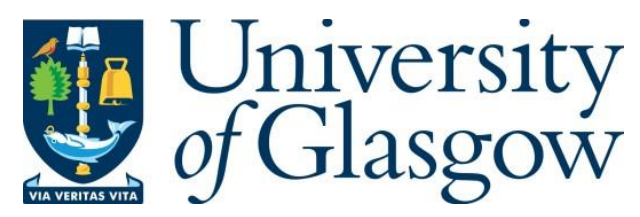

Forbes, A. (2017) Grassland management and helminth control on cattle farms.

Livestock, 22(1), pp. 12-17.

There may be differences between this version and the published version. You are advised to consult the publisher's version if you wish to cite from it.

http://eprints.gla.ac.uk/154529/

Deposited on: 13 February 2018

Enlighten - Research publications by members of the University of Glasgow http://eprints.gla.ac.uk 


\section{Grassland management and helminth control on cattle farms}

Andrew Forbes. Scottish Centre for Production Animal Health and Food Safety, School of Veterinary Medicine, University of Glasgow, G61 1QH

\section{Introduction}

Responsible use of medicines has become a rallying call for the veterinary profession and the British Veterinary Association (BVA) has issued various guidelines, including one for anthelmintics, in which, first in a list of nine 'Dos' is:

"Ensure full grazing management programmes and the use of regular faecal egg counts to ensure treatment of only those animals that need it."

Whilst the intention and sentiments behind this recommendation are not in dispute, feedback from teaching, veterinary meetings and conducting CPD indicates that there is a lack of knowledge and confidence amongst veterinary surgeons with respect to giving advice on grazing management for parasite control. The purpose of this article is to provide summary information of the evidence for, and implementation of, grazing management practices that can mitigate the impact of parasitic gastroenteritis (PGE) - and lungworm - on cattle-only farms. A second article will cover additional grazing management options on farms where mixed livestock species (cattle and sheep) are grazed and this will include the control of liver (and rumen) fluke.

\section{Grazing management}

Farmers manage their pastures and grazing animals primarily to ensure that swards provide adequate, quality nutrients for animal production. To this end, it is important that farm animal veterinary surgeons are familiar with common grassland management practices that farmers follow in order to meet these objectives, as any additional measures to control parasites will have to be incorporated without losing sight of these objectives. Standard textbooks (Hopkins, 2000, Frame and Laidlaw, 2011) are good for obtaining basic information and there are several useful web-sites, for example http://beefandlamb.ahdb.org.uk/, https://dairy.ahdb.org.uk/. The British Grassland Society (BGS) http://www.britishgrassland.com/ holds conferences, provides regular newsletters and publishes Grass and Forage Science, a peer-reviewed journal.

\section{Aspects of the biology of helminths pertinent to grazing management}

The common helminth parasites of cattle (and sheep) have free-living stages that develop on pasture - in dung pats or in intermediate snail hosts that inhabit fields - and infections are acquired when animals ingest infective larvae or metacercariae while grazing. Thus, in essence, the aim of helminth-targeted grazing management is to minimise, or at least limit, the contact between infective stages and their hosts, thereby reducing the challenge and impact of the parasitic stages. In order to implement such practices, a working knowledge of helminth biology, life cycles and epidemiology is required.

Biodynamics of free-living stages of common parasitic nematodes of cattle 
The development times for Ostertagia ostertagi and Cooperia oncophora eggs and Dictyocaulus viviparus larvae in dung are temperature dependent and infective larvae can appear within a week or less over a range of $14-23^{\circ} \mathrm{C}$ (Rose, 1956, Rose, 1961, Rose, 1962, Rose, 1963), temperatures that are common from early to late summer in most parts of the United Kingdom (UK). Translocation of infective larvae from the dung pat onto the surrounding herbage is moisture-dependent. Active horizontal and vertical movement by larvae from the pat is quite limited, typically of the order of up to $50 \mathrm{~mm}$ (Rose, 1956, Williams and Bilkovich, 1973). Travel over such short distances is unlikely to result in larvae being located in the sward where there is a high likelihood of being ingested, as cattle do not generally graze in close proximity to (fresh) faeces of their own species (Marsh and Campling, 1970). Rainfall has been shown to be an important vector for infective larvae and the kinetic energy generated by large raindrops on dung pats can splash larvae out of the pat for distances of around a metre, which greatly enhances the opportunities for ingestion by grazing cattle (Gronvold, 1984, Gronvold, 1987). Another mechanism for the dissemination of larvae, which has been observed mainly in lungworm, is ejection from the pat through spore dispersal mechanisms in common, dung-associated fungi of the genus Pilobolus. (Doncaster, 1981, Jorgensen et al., 1982). These fungi complete the reproductive stage of their life cycle on dung within the same time frame as the development of $D$. viviparus larvae.

In addition to knowledge of the development and ecology of nematode larvae, the survival times of infective larvae on pasture needs to be known in order that the level of contamination and associated risk of acquiring infection can be assessed. None of the three larval stages of $D$. viviparus feed and only the first and second stage larvae of $O$. ostertagi and $C$. oncophora feed (on bacteria), so the third stage infective larvae are entirely dependent on stored energy for metabolism - and ultimately - survival. Metabolism in invertebrates is temperature-dependent, so depletion of energy stores takes place faster at higher ambient temperatures. This leads to the observation that larval survival time may be shorter over a mild winter, though the impact of this on parasite epidemiology may be somewhat modified if housing is later and turnout earlier because of more grass growing days, resulting in a reduced interval between grazing seasons. The converse of this is that when winters are consistently cold, such as in northern latitudes, larval survival can be high over winter and pastures may pose a significant risk to grazing cattle soon after turnout (Nansen et al., 1989).

Under hot, dry conditions on short swards, survival of nematode larvae can be quite short, $>4$ weeks for lungworm larvae, for example (Rose, 1956, Michel and Rose, 1954), however, under more benign conditions the infective larvae of lungworms can survive for six months or more (Rose, 1956) and gastrointestinal (GI) nematodes for a year or more (Rose, 1961). Thus in the context of grazing management, in the absence of any control measures, it should be assumed that any pasture grazed by cattle over the previous 12 months is infective. Cattle have been observed to suffer clinical dictyocaulosis and ostertagiosis on silage aftermaths that had not been grazed since the previous year (Armour et al., 1980).

\section{Grazing management for control of bovine parasitic gastroenteritis}

Probably more than any other element of parasite control, the use of grazing management as a tool is wholly farm dependent. Aspects such as topography, infrastructure, type of farm and livestock enterprise can all affect the feasibility of parasite-oriented pasture management; layered over these components are individual farmer attitudes and aspirations. At one extreme, for example, a hill 
farmer with only cattle and minimal low ground might find it almost impossible to actively manage his land for worm control, on the other hand, a lowland arable farmer who uses grass or forage crops in rotation with corn or other arable crops, may be able to manage fields in a way that ensures a low risk of exposure to parasites. In this article, management options on cattle-only farms will be considered; the focus will be on PGE, as infections with $O$. ostertagi and $C$. oncophora are ubiquitous and the scientific evidence base is strongest for the control of these species.

A number of animal/grazing management practices to control PGE have been studied in cattle farming systems, but, as can be seen from the age of some of the references (ADAS, 1980), this is not currently a very active area of research. Nonetheless, it is assumed that the principles remain valid and that results can be extrapolated to livestock farming in the $21^{\text {st }}$ century. Examples will be drawn from the northern European literature to illustrate important features of the various options; most commonly the focus for control is in first grazing season (FGS), weaned calves.

\section{- Mixed-age systems}

\section{Set-stocked on single pastures}

Though protective immunity to the common Gl nematodes in cattle is incomplete, generally yearlings in their second grazing season (SGS) have developed a strong immunity to $C$. oncophora and a partial immunity to $O$. ostertagi, manifest most obviously as reductions in faecal egg counts (FEC); hence pasture contamination with eggs of these species tends to be lower in SGS and adult cattle than in first grazing season (FGS), weaned calves. Research has shown that if FGS and SGS cattle are grazed together, the FGS calves grew more $(96 \mathrm{~kg})$ over the grazing season than when grazed as a single age group ( $74 \mathrm{~kg}$ ), however, clinical PGE was not completely controlled in the FGS animals and the co-grazed SGS animals suffered a slight growth depression compared to SGS grazing alone (Nansen et al., 1990).

Rotational grazing: Leader-follower

Another approach to mixed-age approaches to worm control is the so-called 'leader-follower' system (Leaver, 1970). This is largely based on a study involving FGS dairy calves and pregnant SGS heifers, where a rotational grazing system was adopted in which calves grazed ahead of the heifers. Blocks of nine paddocks were used and the rotation around these paddocks was completed in 35 days, though, depending on grass growth, not every paddock was grazed every time. Calves were moved on to fresh grazing when the herbage was judged to have been grazed to a level that still allowed adequate herbage for the heifers that followed the calves on to the same paddock. Performance in these groups was compared to calves and heifers grazing in a similar system, but kept separately within the same age-groups. All animals had been vaccinated against lungworm before the start of the trial. The mean daily live weight gain over the grazing season in untreated calves in the leader-follower system was $0.81 \mathrm{~kg}$; that in the untreated calves grazing by themselves was $0.39 \mathrm{~kg}$. The growth rates of the SGS heifers was $0.78 \mathrm{~kg} /$ day when they followed calves, 0.84 $\mathrm{kg} /$ day when they grazed in a single-age group, thus the performance of the heifers was only marginally affected by grazing after the calves.

- Stocking rate (SR) 
Although it appears intuitive that higher stocking rates would result in higher levels of nematode challenge, there are confounding factors, for example sward characteristics under various grazing regimes, which can affect both parasites and nutrition. An example of a study in which SR had an effect on PGE in FGS calves was conducted in Denmark (Hansen et al., 1981) using stocking rates of 6, 8.5 and 10.5 calves per hectare. The calves that remained on the same paddocks throughout the grazing season had live weight gains of 58,28 and $19 \mathrm{~kg}$ at the low, medium and high SRs, respectively; clinical PGE and high (3.6-3.9 IU) plasma pepsinogen concentrations were observed in the medium and high group animals. Calves kept at the same stocking rates, but moved to silage aftermaths in July gained 72, 63 and $46 \mathrm{~kg}$ respectively, suffered no clinical PGE and had pepsinogen values ranging from 1.3-2.1 IU.

- Delayed turnout

In the absence of grazing cattle, populations of over-wintered GI nematode larvae surviving on pasture decline in spring and early summer so that by mid-July pastures pose a low risk of PGE. This forms the basis for several approaches to control such as late turnout, move to aftermaths in July with or without anthelmintic treatment - and the strategic, early-season use of anthelmintics (Michel, 1968, Armour et al., 1987). The actual timing of the nadir in pasture larvae may vary somewhat according to latitude, weather and farming practices, but the principle holds good in many parts of northern Europe. Late turnout may be incompatible with optimal use of grassland on many farms, but it has been shown to reduce the PGE challenge and reduce its impact. In a study in Denmark, calves turned out in mid-June and maintained on the same pasture for the remainder of the grazing season gained more weight $(39 \mathrm{~kg}$ ) than those turned out in mid-May (Nansen et al., 1987). Another group of calves that was turned out at the same time in May, but which were moved to a low risk pasture in early July, gained $31 \mathrm{~kg}$ more than those that weren't moved, demonstrating the benefits for moving calves off potentially high risk pastures in July.

- Mid-grazing season (July) move to low-risk pasture (aftermaths)

The examples in the previous two sections, in addition to studying the effects of late turnout and stocking rate, have included groups of cattle moved to low-risk pastures in July. The rationale for this approach is the essentially stereotypical pattern of larval challenge on permanent pasture grazed by set-stocked, weaned FGS calves, in the absence of any anthelmintic treatment (Michel, 1969). This allows the adoption of a number of control measures that are predicated either on preventing/limiting the mid-season build-up of infective larvae or moving susceptible cattle away from the pasture in advance of peak larval numbers (ADAS, 1980).

In one of the original studies on mid-season moves, low risk pastures were created by treating calves intensively with anthelmintics between turnout and July so that the sward characteristics and dung deposition of the paddocks were identical when the moves took place, thus ensuring that any differences could be attributed to parasitism, not agronomic factors (Michel, 1968). This study was repeated over three successive years and comprised three treatment groups: 1) grazed the whole grazing season on the same paddock without anthelmintic treatment; 2) as per group 1, but moved to a low risk pasture in mid-July; 3 ) as per group 2 , but dosed with an anthelmintic when transferred to the low risk paddock - 'dose-and-move'. 
Over the first two years of the study, calves in in groups 2 and 3, which were moved in mid-July, grew steadily over the grazing season and their live weight gains were similar at $\sim 115 \mathrm{~kg}$ and $\sim 82 \mathrm{~kg}$ in years 1 and 2 respectively. Corresponding live weight gains in the calves that remained on the same paddock throughout (Group 1) were $\sim 45 \mathrm{~kg}$ and $\sim 32 \mathrm{~kg}$; their growth rates matched those of the other groups until mid-July, after which growth plateaued and some weight loss was observed. The results in the third year were slightly different insofar as, whilst the weight gain of the calves that weren't moved remained poor at $\sim 32 \mathrm{~kg}$ and the gain in the dose-and-move calves was $\sim 115 \mathrm{~kg}$, in the calves that were moved but not treated, the weight gain was $\sim 80 \mathrm{~kg}$ (Figure 1). This poorer performance was attributed to an increase in pasture larval contamination in August, presumably as a consequence of the untreated calves having carried high faecal egg counts on to the low risk pasture, leading to a subsequent increase in larval challenge.

Evidence that these differences in performance were associated with parasitism is provided through measures of abomasal mass. The development of $O$. ostertagi takes place in the gastric glands of the abomasum, where host cellular responses result in visible lesions, which provide a measure of pathology resulting from ostertagiosis (Larraillet et al., 2012, Murray et al., 1970, Williams, 1991). The impact of the three regimes on parasitism was the observation over the three years of the study at post mortem of increased abomasal mass as a percentage of live weight in the unmoved calves (1.2\%), compared to $0.65 \%$ and $0.50 \%$ in the group 2 and 3 animals, respectively (Michel, 1968).

\section{'Dose-and-Move'}

Moving stock onto a low risk pasture, coupled with a single anthelmintic treatment, can mitigate the impact of PGE (Eysker et al., 1998) and compares favourably with parasite control systems using three or more anthelmintic treatments over a whole grazing season. Nevertheless, following early studies on the role of refugia in the selection for anthelmintic resistance (Martin et al., 1981), it was speculated that dose-and-move might exert a high selective pressure on worms carrying genes for resistance (Michel, 1985). Awareness of this potential problem was heightened in the 2000s (van Wyk, 2001) and since then the practice of dose-and-move has been widely condemned by many parasitologists, veterinarians and advisors. Yet the scientific evidence base for this risk, its magnitude and the trade-offs in terms of effective worm control and animal performance is equivocal and based largely on sheep (Barnes et al., 1995, Falzon et al., 2014, Waller et al., 1989, Crilly and Sargison, 2016).

In two of the very few field studies in the literature, which were conducted in sheep in New Zealand (Waghorn et al., 2008, Waghorn et al., 2009), the sensitivity of the worm isolates to benzimidazoles was slightly reduced (as measured in vitro) by the end of the grazing season after dose-and-move had been used. The protocols did not include a positive control group, nor were performance data provided. Whilst the latter is of importance in terms of likely adoption by farmers, it is less important per se in terms of resistance management, however, the absence of a positive control group means that there is no way of determining whether dose-and-move was more selective for resistance than standard worming practices. In New Zealand, recommendations for lambs on permanent pastures are to treat them with anthelmintics at $\sim 4$ week intervals on up to 5-6 occasions (Vlassoff and Brunsdon, 1981) and it appears that this practice remains common (Leathwick et al., 2015); high frequency anthelmintic treatments over extended time periods are known to be a risk factor for 
resistance selection both through observation and epidemiological studies (Falzon et al., 2014, Scott et al., 2013)

Dose-and-move is a practice that has benefits in terms of PGE control, utilisation of herbage and reduced use of anthelmintics. If dose-and-move does select more rapidly for resistance than alternative treatment practices, then appropriate mitigation measures should be adopted with the objective of minimising the contribution of resistant genotypes to subsequent worm generations. Many of these suggestions suffer from the same lack of rigorous scientific studies to support them as the speculation that surrounds the potential dangers of dose-and-move and are therefore, of necessity derived using assumptions and extrapolations from what science is available. Some examples are provided in Box 1.

\section{Grazing management for control of parasitic bronchitis}

Several of the grazing management practices for the control of PGE in cattle are based on the predictable annual pattern of pasture infectivity in untreated, weaned, grazing cattle, however, the epidemiology of lungworm does not follow the same patterns and is unpredictable (Jacobs and Fox, 1985, Duncan et al., 1979, Eysker and van Miltenburg, 1988). Furthermore, older cattle can play an important role as carriers of infection, including over-winter (Eysker et al., 1994, Saatkamp et al., 1994), and hence any mixed age systems in cattle may expose youngstock to the risk of husk/hoose. However, it has been shown that grazing immune, non-carrier dry cows on contaminated pasture in the autumn can considerably reduce the numbers of infective D. viviparus larvae (Baxter et al., 1959). Systems that have been found to be of value in the control of PGE have generally been shown to be unreliable (or impractical) in the control of dictyocaulosis (Eysker et al., 1993, Armour et al., 1980), however, dose-and-move can be effective (Eysker et al., 1995a, Eysker et al., 1995b). In summary, grazing management practices aimed at controlling PGE in calves may also help in the control of lungworm, however care must be taken in mixed-age groupings; vaccination against $D$. viviparus would help in the implementation of PGE control at grass by minimising the risk of husk.

\section{Conclusion}

Grazing management can contribute to the control of parasites in cattle at grass and mitigate their effects; it assumes great importance in helping to reduce (over-) reliance on anthelmintics and is of particular value in low input systems and organic livestock farming. The application of the practices outlined in this article depends very largely on farm infrastructure and farmer aspirations and must of necessity therefore be customised accordingly. Of all the management options described, possibly the ones with most potential for adoption on cattle-only farms are those that utilise silage or hay aftermaths from mid-July onwards. It can be assumed that the vast majority of grass-based cattle farms will conserve forages and therefore will have aftermaths available, though there may be some conflicts between their use as low risk pastures for young stock and utilisation by high performing stock such as dairy cows, to capitalise on the high nutritional value of pasture regrowth.

\section{References}

ADAS 1980. Booklet 2154. Grazing plans for the control of stomach and intestinal worms in sheep and in cattle. Ministry of Agriculture, Fisheries and Food

ARMOUR, J., AL SAQUR, I. M., BAIRDEN, K., DUNCAN, J. L. \& URQUHART, G. M. 1980. Parasitic bronchitis and ostertagiasis on aftermath grazing. Veterinary Record, 106, 184-185. 
ARMOUR, J., BAIRDEN, K., PIRIE, H. M. \& RYAN, W. G. 1987. Control of parasitic bronchitis and gastroenteritis in grazing cattle by strategic prophylaxis with ivermectin. Vet Rec, 121, 5-8.

BARNES, E. H., DOBSON, R. J. \& BARGER, I. A. 1995. Worm control and anthelmintic resistance: adventures with a model. Parasitol Today, 11, 56-63.

BAXTER, J. T., ALLAN, D. \& PATTERSON, J. T. 1959. The influence of grazing "immune cows" on the level of Dictyocaulus viviparus infection on pasture. Journal of the British Grassland Society, 14, 293-297.

CRILLY, J. P. \& SARGISON, N. 2016. Macrocyclic lactone resistance on new grass leys - the putative role of accidental 'dose-and-move' strategies due to the use of persistent macrocyclic lactone products. Livestock, 21, 173-178.

DONCASTER, C. C. 1981. Observations on relationships between infective juveniles of bovine lungworm, Dictyocaulus viviparus (Nematoda: Strongylida) and the fungi, Pilobolus kleinii and P. crystallinus (Zygomycotina: Zygomycetes). Parasitology, 82, 421-8.

DUNCAN, J. L., ARMOUR, J., BAIRDEN, K., URQUHART, G. M. \& JORGENSEN, R. J. 1979. Studies on the epidemiology of bovine parasitic bronchitis. Veterinary Record, 104, 274-8.

EYSKER, M., BOERSEMA, J. H., CORNELISSEN, J. B. \& KOOYMAN, F. N. 1995a. Efficacy of Michel's 'dose and move' system against Dictyocaulus viviparus infections in cattle using moxidectin as anthelmintic. Veterinary Parasitology, 58, 49-60.

EYSKER, M., BOERSEMA, J. H., CORNELISSEN, J. B., KOOYMAN, F. N., DE LEEUW, W. A. \& SAATKAMP, H. W. 1993. The effect of rotational grazing for periods of one or two weeks on the build-up of lungworm and gastro-intestinal nematode infections in calves. Vet $Q, 15,20-4$.

EYSKER, M., BOERSEMA, J. H., KOOYMAN, F. N. \& LAM, T. J. 1995b. The combined effect of fenbendazole treatment and a move to aftermath 7 or 9 weeks after turnout on Dictyocaulus viviparus infections in calves. Veterinary Parasitology, 60, 339-48.

EYSKER, M., CLAESSENS, E. W., LAM, T. J., MOONS, M. J. \& PIJPERS, A. 1994. The prevalence of patent lungworm infections in herds of dairy cows in The Netherlands. Vet Parasitol, 53, 263-7.

EYSKER, M., VAN DER AAR, W. M., BOERSEMA, J. H., DOP, P. Y. \& KOOYMAN, F. N. 1998. The efficacy of Michel's dose and move system on gastrointestinal nematode infections in diary calves. Veterinary Parasitology, 75, 99-114.

EYSKER, M. \& VAN MILTENBURG, L. 1988. Epidemiological patterns of gastrointestinal and lung helminth infections in grazing calves in The Netherlands. Veterinary Parasitology, 29, 29-39.

FALZON, L. C., O'NEILL, T. J., MENZIES, P. I., PEREGRINE, A. S., JONES-BITTON, A., VANLEEUWEN, J. \& MEDEROS, A. 2014. A systematic review and meta-analysis of factors associated with anthelmintic resistance in sheep. Preventive veterinary medicine, 117, 388-402.

FRAME, J. \& LAIDLAW, A. S. 2011. Improved Grassland Management, The Crowood Press.

GRONVOLD, J. 1984. Rain splash dispersal of third-stage larvae of Cooperia spp. (Trichostrongylidae). J Parasitol, 70, 924-6.

GRONVOLD, J. 1987. A field experiment on rain splash dispersal of infective larvae of Ostertagia ostertagi (Trichostrongylidae) from cow pats to surrounding grass. Acta Vet Scand, 28, 45961.

HANSEN, J. W., NANSEN, P. \& FOLDAGER, J. The importance of stocking rate to the uptake of gastrointestinal nematodes by grazing calves. In: NANSEN, P., JORGENSEN, R. J. \& SOULSBY, E. J. L., eds. Epidemiology and Control of Nematodiasis in Cattle, 1981 Copenhagen. Martinus Nijhoff, 471-494.

HOPKINS, A. 2000. Grass: Its Production \& Utlisation, British Grassland Society.

JACOBS, D. E. \& FOX, M. T. 1985. Relationship between date of spring turnout and lungworm infection in calves. Veterinary Record, 116, 75-6.

JORGENSEN, R. J., RONNE, H., HELSTED, C. \& ISKANDER, A. R. 1982. Spread of infective Dictyocaulus viviparus larvae in pasture and to grazing cattle: experimental evidence of the role of Pilobolus fungi. Veterinary Parasitology, 10, 331-9. 
LARRAILLET, L., FORBES, A. B. \& PRAVIEUX, J. J. 2012. Abattoir survey of abomasal lesions associated with ostertagiosis in adult cattle. Veterinary Record, 171, 299.

LEATHWICK, D. M., GANESH, S. \& WAGHORN, T. S. 2015. Evidence for reversion towards anthelmintic susceptibility in Teladorsagia circumcincta in response to resistance management programmes. Int J Parasitol Drugs Drug Resist, 5, 9-15.

LEAVER, J. D. 1970. A comparison of grazing systems for dairy herd replacements. Journal of Agricultural Science, 75, 265-272.

MARSH, R. \& CAMPLING, R. C. 1970. Fouling of pastures by dung. Herbage Abstracts, 40, 123-130.

MARTIN, P. J., LE JAMBRE, L. F. \& CLAXTON, J. H. 1981. The impact of refugia on the development of thiabendazole resistance in Haemonchus contortus. International Journal for Parasitology, 11, 35-41.

MICHEL, J. F. 1968. The control of stomach-worm infection in young cattle. Journal of the British Grassland Society, 23, 165-173.

MICHEL, J. F. 1969. Observations on the epidemiology of parasitic gastro-enteritis in calves. J Helminthol, 43, 111-33.

MICHEL, J. F. 1985. Strategies for the use of anthelmintics in livestock and their implications for the development of drug resistance. Parasitology, 90, 621-8.

MICHEL, J. F. \& ROSE, J. H. 1954. Some observations on the free living stages of the cattle lungworm in relation to their natural environment. J Comp Pathol, 64, 195-205.

MURRAY, M., JENNINGS, F. W. \& ARMOUR, J. 1970. Bovine ostertagiasis: structure, function and mode of differentiation of the bovine gastric mucosa and kinetics of the worm loss. Res Vet Sci, 11, 417-27.

NANSEN, P., GRONVOLD, J., JORGENSEN, R. J., HENRIKSEN, S. A., FOLDAGER, J. \& SEJRSEN, K. 1989. Outbreaks of early-season trichostrongylosis in calves in Denmark. Veterinary Parasitology, 32, 199-211.

NANSEN, P., JORGENSEN, R. J., HENRIKSEN, S. A. \& FOLDAGER, J. 1987. The effects of late turnout on the epidemiology and control of ostertagiasis in calves. Veterinary Parasitology, 24, 139-47.

NANSEN, P., STEFFAN, P., MONRAD, J., GRONVOLD, J. \& HENRIKSEN, S. A. 1990. Effects of separate and mixed grazing on trichostrongylosis in first- and second-season grazing calves. Veterinary Parasitology, 36, 265-76.

ROSE, J. H. 1956. The bionomics of the free-living larvae of Dictyocaulus viviparus. J Comp Pathol, 66, 228-40.

ROSE, J. H. 1961. Some observations on the free-living stages of Ostertagia ostertagi, a stomach worm of cattle. Parasitology, 51, 295-307.

ROSE, J. H. 1962. Further observations on the free-living stages of Ostertagia ostertagi in cattle. J Comp Pathol, 72, 11-8.

ROSE, J. H. 1963. Ecological Observations and Laboratory Experiments on the Free-Living Stages of Cooperia oncophora. J Comp Pathol, 73, 285-96.

SAATKAMP, H. W., EYSKER, M. \& VERHOEFF, J. 1994. Study on the causes of outbreaks of lungworm disease on commercial dairy farms in The Netherlands. Vet Parasitol, 53, 253-61.

SCOTT, I., POMROY, W. E., KENYON, P. R., SMITH, G., ADLINGTON, B. \& MOSS, A. 2013. Lack of efficacy of monepantel against Teladorsagia circumcincta and Trichostrongylus colubriformis. Veterinary Parasitology, 198, 166-71.

VAN WYK, J. A. 2001. Refugia--overlooked as perhaps the most potent factor concerning the development of anthelmintic resistance. Onderstepoort J Vet Res, 68, 55-67.

VLASSOFF, A. \& BRUNSDON, R. V. 1981. Control of gastro-intestinal nematodes: advantages of a preventive anthelmintic drench programme for lambs on pasture. New Zealand Journal of Experimental Agriculture, 9, 221-225.

WAGHORN, T. S., LEATHWICK, D. M., MILLER, C. M. \& ATKINSON, D. S. 2008. Brave or gullible: testing the concept that leaving susceptible parasites in refugia will slow the development of anthelmintic resistance. $N Z$ Vet J, 56, 158-63. 
WAGHORN, T. S., MILLER, C. M., OLIVER, A. M. \& LEATHWICK, D. M. 2009. Drench-and-shift is a highrisk practice in the absence of refugia. $N Z$ Vet J, 57, 359-63.

WALLER, P. J., DONALD, A. D., DOBSON, R. J., LACEY, E., HENNESSY, D. R., ALLERTON, G. R. \& PRICHARD, R. K. 1989. Changes in anthelmintic resistance status of Haemonchus contortus and Trichostrongylus colubriformis exposed to different anthelmintic selection pressures in grazing sheep. International Journal for Parasitology, 19, 99-110.

WILLIAMS, J. C. 1991. Efficacy of albendazole, levamisole and fenbendazole against gastrointestinal nematodes of cattle, with emphasis on inhibited early fourth stage Ostertagia ostertagi larvae. Veterinary Parasitology, 40, 59-71.

WILLIAMS, J. C. \& BILKOVICH, F. R. 1973. Distribution of Ostertagia ostertagi infective larvae on pasture herbage. Am J Vet Res, 34, 1337-44. 